\title{
Adsorption of Pyridine onto Activated Montmorillonite Clays: Effect Factors, Adsorption Behavior and Mechanism Study
}

\author{
Zeinab Ibrahim 1,2, Bachar Koubaissy2*, Yehya Mohsen1, Tayssir Hamieh"1, T. Jean Daou ${ }^{3}$, \\ Habiba Nouali ${ }^{3}$, Maria-Laura Foddis ${ }^{4}$, Joumana Toufaily ${ }^{2 *}$
}

\author{
${ }^{1}$ Laboratoire Matériaux, Catalyse, Environnement et Méthodes Analytiques (MCEMA), EDST, FS, Université Libanaise, Campus \\ Hariri, Hadath, Beyrouth, Lebanon \\ ${ }^{2}$ Laboratoire des Etudes Appliquées au Développement Durable et Energie Renouvelable (LEADDER), EDST, Université \\ Libanaise, Campus Hariri, Hadath, Beyrouth, Lebanon \\ ${ }^{3}$ Université de Strasbourg, Université de Haute Alsace, Axe Matériaux à Porosité Contrôlée (MPC), Institut de Science des \\ Matériaux de Mulhouse (IS2M), UMR CNRS 7361, ENSCMu, 3 bis rue Alfred Werner, Mulhouse Cedex, France \\ ${ }^{4}$ DICAAR-Dipartimento di Ingegneria Civile Ambientale e Architecttura, Università de Cagliari, Cagliari, Italy \\ Email: ^bachar.kobaissy@ul.edu.lb, joumana.toufaily@ul.edu.lb
}

\begin{abstract}
How to cite this paper: Ibrahim, Z., Koubaissy, B., Mohsen, Y., Hamieh, T., Daou, T.J., Nouali, H., Foddis, M.-L. and Toufaily, J. (2018) Adsorption of Pyridine onto Activated Montmorillonite Clays: Effect Factors, Adsorption Behavior and Mechanism Study. American Journal of Analytical Chemistry, 9, 464-481. https://doi.org/10.4236/ajac.2018.910035
\end{abstract}

Received: September 10, 2018

Accepted: October 19, 2018

Published: October 22, 2018

Copyright $\odot 2018$ by authors and Scientific Research Publishing Inc. This work is licensed under the Creative Commons Attribution International License (CC BY 4.0).

http://creativecommons.org/licenses/by/4.0/

\section{(c) (i) Open Access}

\begin{abstract}
Activated Montmorillonite was applied for the sorption of pyridine as a health-toxic substance. Fourier-transform Infrared spectroscopy (FTIR), zeta potential analysis, thermogravimetric analysis (TGA), $\mathrm{N}_{2}$ physisorption analysis and X-ray diffraction (XRD) method were used to investigate the structure and composition of Montmorillonite. The batch sorption system was used to study the effect of different parameters on the adsorption. Results had shown that neutral $\mathrm{pH}$ had a significant effect on the sorption of pyridine; thermodynamic calculations indicated that the adsorption of pyridine over Montmorillonite was exothermic reaction and the equilibrium capacity was slightly increased by using $\mathrm{H}_{2} \mathrm{SO}_{4}$ as activating agent by comparison with that obtained by using $\mathrm{HCl}$ and $\mathrm{H}_{3} \mathrm{PO}_{4}$. Fitting the experimental data to isotherms models indicated that the experimental data were well fitted by Fowler Guggenheim isotherm models. Finally the results obtained by FTIR and TGA proved that the relative affinity of the pyridine toward the Montmorillonite was related to the electron donor-acceptor complexes that were formed between the basic sites (nitrogen or oxygen) and hydrogens (acidic site).
\end{abstract}

\section{Keywords}

Adsorption, Pyridine, Montmorillonite, Chemical Treatment, Surface Properties 


\section{Introduction}

The presence of organic pollutants in the ecosystem is the most important environmental problem in the world. The literature reviewed that there has been a high increase in production and utilization of organic pollutants in last few decades resulting in a big threat of pollution [1]. Efficient techniques for the removal of highly toxic organic compounds from water and wastewater have drawn significant interest [2].

Among the different organic pollutants in wastewater, pyridine behaves as an interesting pollutant. In fact, it is a basic heterocyclic organic compound [3], which persists for longer duration in water. It is widely used as a solvent and intermediate in the production of agricultural chemicals, drugs, dyestuffs and paints, rubber products, polycarbonate resins and textile water-repellents, as well as in laboratories [4]. Pharmaceutical agents are manufactured using pyridine as catalyst [2]. Therefore, increasing amounts of pyridine containing waste water is generated by various industries, and considered toxic even at low concentrations to aquatic life and produce nuisance because of the malodorous and pungent smell [5].

The different physico-chemical methods of pyridine elimination from water stream have been developed and they are known as biodegradation [2] [6], chemical oxidation [6], ozonation [2], and adsorption phenomenon's [7].

Among them, adsorption method is recognized as an effective and low cost technique for the removal of organic pollutants from water and wastewater, and it produces a high-quality treated effluent [8]. Therefore, several adsorbents were used for the treatment of wastewater and especially for the removal of pyridine such as activated carbon, zeolites and clay minerals [9].

Activated carbon is considered as the most widely used adsorbent because of its highly adsorption capacity. However, adsorption over activated carbon remains an expensive process due to the difficult regeneration of this material [4] [10] [11].

Industrial zeolites have been used with specific properties for various applications [12] [13], but due to their high cost and the complexity of their regeneration, the application of this type of adsorbents is limited [14].

Consequently, in order to design efficient, inexpensive, ecological and recyclable materials [15], inorganic material especially Smectite group such as Montmorillonite, have been widely investigated [10] [16].

Montmorillonite is a member of the Smectite group expandable 2:1 layer-type of clay materials [17]. This dioctahedral clay is composed of staked alumino-silicate layers [18]. The silica tetrahedra $(\mathrm{T})\left(\mathrm{Si}^{4+}\right.$ in tetrahedral coordination with $\left.\mathrm{O}^{2-}\right)$ and alumino octahedra $(\mathrm{O})\left(\mathrm{Al}^{3+}\right.$ in octahedral coordination with $\left.\mathrm{O}^{2-}\right)$ are interconnected (by the sharing of $\mathrm{O}^{2-}$ at polyhedral corners and edges) in such a way that a sheet of alumina octahedral is sandwiched between two sheets of silica tetrahedral, thus making the composition of T-O-T layer [19].

According to many authors, silane is readily intercalated into the interlayer 
space, in the swelling clay minerals such as Montmorillonite [19] [20].

Chemical modifications on the surface of clay were also conducted to improve their sorption capacity [17]. Indeed, surface modification of clay minerals has attracted much attention because the obtained products exhibiting properties suitable for many applications in material science [21].

Clays such as Montmorillonite can bind a large number of organic molecules because of their large specific surface areas and of their Van der Waals, ion-dipole, and/or dipole-dipole interactions [22].

In the present work, several characterization techniques especially Fourier-Transform Infra-Red (FTIR), X-ray diffraction (XRD) and Zetametry were used in order to identify the changes in the structure and properties of the Montmorillonite clay.

More precisely, this work aimed to study in one hand the removal of organic molecules such as Pyridine in wastewater over Montmorillonite clay, and on the other hand, to compare the adsorption capacity of the activated and non-activated Montmorillonite. In this context and in order to achieve these goals, adsorption process was conducted in a batch apparatus where the effect of various parameters, such as adsorbent dose, $\mathrm{pH}$ and temperature was studied.

Furthermore, we have tried to highlight the effect of the acidic and alkaline treatments of the Montmorillonite clay.

\section{Experimental Part}

The clay adsorbent used in this investigation was the Montmorillonite K10 (labeled MK10) and it was supplied from Sigma Aldrich. The MK10 samples used in this study consisted of crystallites with an average size of 2 micrometer.

A stock solution was of the test reagents were made by dissolving pyridine in deionized water.

\subsection{Activation Process}

Montmorillonite (MK10) was treated with various types of chemical activation agents especially with inorganic acids such as hydrochloric acid, sulfuric acid and phosphoric acid solutions and with a base $(\mathrm{NaOH})$. The treatments with the three acids are prepared according to a standard calculation procedure given in the literature [16].

The MK10 sample is treated by acid solution or a $\mathrm{NaOH}$ solution, and then the resulting suspension is stirred at room temperature for $24 \mathrm{~h}$. After that, the resulting slurry is poured into a Büchner funnel to separate the acid and the Montmorillonite. The residual Montmorillonite is washed several times with distilled water until a neutral $\mathrm{pH}$. After collection, each clay sample is dried at $105^{\circ} \mathrm{C}$ for $4 \mathrm{~h}$.

The used concentration of all activating agents is fixed to $0.5 \mathrm{~mol} / \mathrm{L}$.

\subsection{Characterization Techniques}

Zeta potentials of Montmorillonite samples were measured at $22^{\circ} \mathrm{C} \pm 1{ }^{\circ} \mathrm{C}$ using 
a Zeta Meter 4.0 equipped with a microprocessor unit (PRASE-EDST, LU, Lebanon).

FT-IR study was carried out using FTIR-6300 apparatus from JASCO (PRASE-EDST, LU, Lebanon). FTIR spectra were recorded in the range of 400 $4000 \mathrm{~cm}^{-1}$ at a resolution of $4 \mathrm{~cm}^{-1}$ with $\mathrm{KBr}$ pellets technique. The samples for FTIR were prepared by mixing the powdered samples with potassium bromide $(1 \% \mathrm{wt} / \mathrm{wt})$ and compressed into $0.7 \mathrm{~cm}$-diameter pellets.

$\mathrm{X}$-ray diffraction patterns were obtained for powder samples, using a D8 Bruker X-ray diffractometer (copper anticathode of wavelength $\lambda \mathrm{Ka}=0.154060$ $\mathrm{nm}$; PRASE-EDST, LU, Lebanon). The data were collected in the $2 \theta$ range of $5^{\circ}$ to $80^{\circ}$ with a step size of $0.02^{\circ}$ per second. The collected diffractograms were analyzed using EVA software.

The microporous and mesoporous volumes and the specific surface area were determined from nitrogen adsorption-desorption isotherms performed at $-196^{\circ} \mathrm{C}$ on a Micromeritics ASAP 2420 apparatus using the DFT, the BET (on a linear $\mathrm{P} / \mathrm{P} 0$ domain between 0.01 and 0.3$)$, and the single-point $\left(\mathrm{P} / \mathrm{P}_{0}=0.26\right)$ methods, respectively (IS2M, UHA, France). The calcined samples were placed in a glass measurement cell, and then they were degased at $350^{\circ} \mathrm{C}$ under vacuum prior to the measurement.

Thermogravimetric analysis was performed in flowing air using a Setaram Labsys thermoanalyser, heated from $30^{\circ} \mathrm{C}$ to $800^{\circ} \mathrm{C}$ at a heating rate of $5^{\circ} \mathrm{C}$ $\mathrm{min}^{-1}$ and was cooled down to room temperature (IS2M, UHA, France).

\subsection{Adsorption Experiment}

Adsorption experiments were performed using a batch equilibration technique. Pyridine (99.5\% purity) was purchased from Sigma Aldrich and labeled Py.

Py characteristics are summarized in Table 1 . The diluted pyridine solutions were prepared in the concentration range of 25 to $250 \mathrm{mg} / \mathrm{L}$ in deionized water. The $\mathrm{pH}$ of the solution was adjusted using $\mathrm{HCl}(0.1 \mathrm{~mol} / \mathrm{L})$ or $\mathrm{NaOH}(0.1 \mathrm{~mol} / \mathrm{L})$ solutions. For each equilibration technique, $40 \mathrm{mg}$ of the MK10 adsorbent was added to $20 \mathrm{ml}$ of Py solution and stirred at room temperature in a batch experiment up the equilibrium. For the determination of the optimum mass, a $20 \mathrm{ml}$ of Py solution was conducted with different dosages of adsorbents (m) till the equilibrium was reached.

For adsorption isotherms, Py solutions of $\mathrm{C}_{0}=25-250 \mathrm{mg} / \mathrm{L}$ were agitated with known mass and incubated in an incubator shaker at different temperatures $20^{\circ} \mathrm{C}, 30^{\circ} \mathrm{C}$ and $40^{\circ} \mathrm{C}$ until reaching equilibrium.

The amount of Py adsorbed at equilibrium was calculated as:

$$
m_{A}(Q)=\left(C_{0}-C_{e}\right) \times V
$$

where $C_{0}$ and $C_{\mathrm{e}}$ are the initial and equilibrium concentrations $(\mathrm{mg} / \mathrm{L})$ of Py in the solution, $V$ is the Volume $(\mathrm{L}), \mathrm{m}_{\mathrm{A}}$ is the mass of the adsorbent $(\mathrm{g})$ and $\mathrm{q}_{\mathrm{e}}$ is the adsorbed amount of Py on the MK10 adsorbent (mg/L). 
Table 1. Physicochemical properties of pyridine [1].

\begin{tabular}{cc}
\hline Chemical formula & $\mathrm{C}_{5} \mathrm{H}_{5} \mathrm{~N}$ \\
\hline Solubility & water and apolar solvents \\
Purity & $99.5 \%$ \\
Molecular mass & 79.1 \\
$\lambda_{\max }$ & $256 \mathrm{~nm}$ \\
pKa & 5.23 \\
Kinetics diameter & $0.6 \mathrm{~nm}$ \\
\hline
\end{tabular}

\section{Results and Discussion}

\subsection{FTIR Characterization}

Fourier-transform Infrared spectroscopy, a relatively simpler and sensitive technique used to study the mineralogical and chemical structure of clay minerals [23] [24].

The FTIR spectra of the untreated and treated Montmorillonite in the wave number range between $4000-400 \mathrm{~cm}^{-1}$ are shown in Figure 1 .

The spectrum of the untreated Montmorillonite exhibits absorption bands at $3630 \mathrm{~cm}^{-1}$, which is assigned to the stretching vibrations of the $\mathrm{OH}$ groups of the octahedral sheets [25] and at $1656 \mathrm{~cm}^{-1}$ which represents the bending vibrations of the $\mathrm{OH}$ groups for the water molecules adsorbed on the surface of the clay. The band at $1046 \mathrm{~cm}^{-1}$ was attributed to the stretching vibration of Si-O (in-plane), whereas the bands around 531 and $469 \mathrm{~cm}^{-1}$ were attributed to $\mathrm{Si}-\mathrm{O}-\mathrm{Al}$ (where $\mathrm{Al}$ is the octahedral cation) and $\mathrm{Si}-\mathrm{O}-\mathrm{Si}$ bending vibrations, respectively. The untreated Montmorillonite spectrum contains bands at $797 \mathrm{~cm}^{-1}$ and $693 \mathrm{~cm}^{-1}$ which are attributed to orthodase and quartz, respectively.

FTIR spectra of Figure 1 show a decrease in intensity as a result of the acidic activation of the Montmorillonite. This reflects the leaching of octahedral cations, from the Montmorillonite structure, causing the loss of water band hydroxyl groups coordinated to them [26].

During the acid treatment of the Montmorillonite, initially interlayer cations are replaced with $\mathrm{H}^{+}$ions followed by dissolution of the aluminum octahedral and silicon tetrahedral sheets with subsequent dissolution of structural cations [24]. FTIR study clearly demonstrates that the acid treatment affects first the octahedral sheet of Montmorillonite clay resulting into the dissolution of octahedral cations [16]. Therefore, the acidification treatment does not affect the crystalline structure of the Montmorillonite. On the other hand, a decrease in the intensity on the $\mathrm{OH}$ group of the absorption bands at 1600 and $3600 \mathrm{~cm}^{-1}$, this may be due to the replacement of $\mathrm{H}_{2} \mathrm{O}$ molecules by those $\mathrm{H}^{+}$after the acidification treatment [27].

In our results, we found that no much variation of the absorption bands in Montmorillonite clay after its activation with different types of acid, an alkaline agent compared with the untreated clay minerals. 


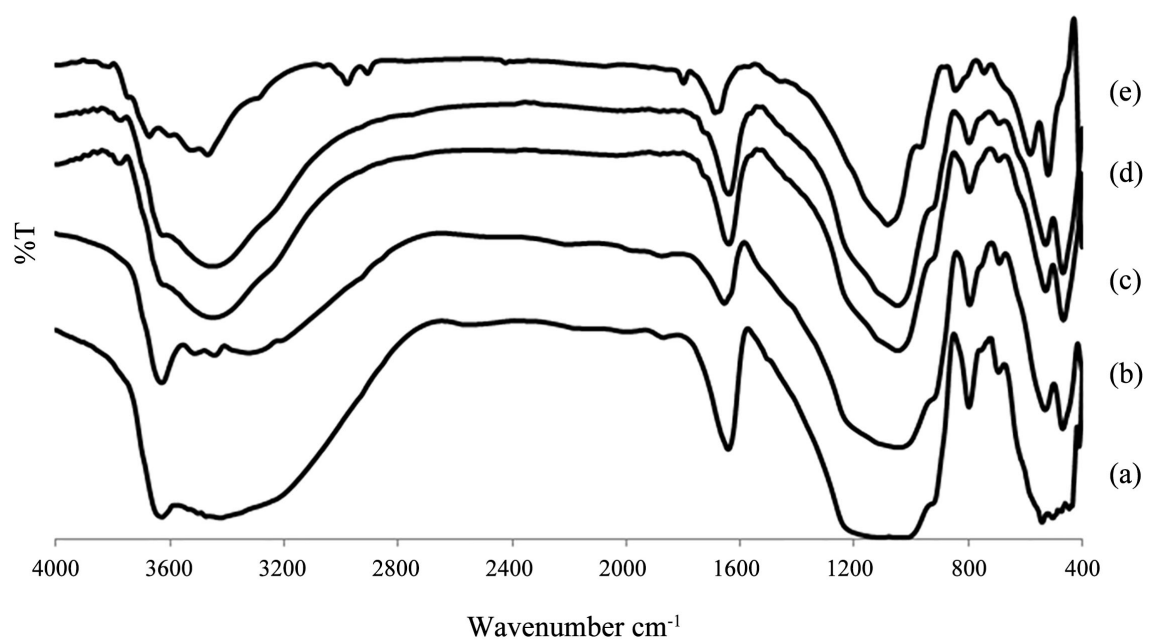

Figure 1. FTIR Spectra of the (a) untreated Montmorillonite, and treated Montmorillonite with: (b) hydrochloric acid, (c) sulfuric acid, (d) phosphoric acid and (e) sodium hydroxide.

\subsection{XRD Characterization}

The XRD patterns of the samples are given in Figure 2, here was no significant difference between the XRD patterns of the different types of activated clay with that of the untreated MK10 clay.

The basal d 001 reflexion at 8.86 of the MK10 untreated and treated with acids remains unchanged.

The corresponding peaks showed no modification of 2 theta values observed at $19.91(003), 20.92(0.20), 26.68(003)$ and others peaks indicated that conservation of two-dimensional lattice [28].

Therefore, the acidification treatment does not affect the crystalline structure of the Montmorillonite. This observation is in agreement with the obtained results of analysis by FTIR.

\subsection{Zeta Potential}

In a range of investigated $\mathrm{pH}$ ( 2 to 11 ), the mobility is negative as observed by the electrophoretic mobilities (Figure 3 ). This negative mobility indicates that the clay is negatively charged.

A previous study reported that [29], the decrease in the absolute value of the zeta potential as the $\mathrm{pH}$ diminished was probably due to the displacement of the equilibrium between the hydrogen of the solution and the hydroxyl groups of the particle edges, according to:

$$
\begin{aligned}
& \mathrm{SO}^{-}+\mathrm{H}^{+}---\mathrm{SOH} \\
& \mathrm{SOH}+\mathrm{H}^{+} \sim \mathrm{SOH}_{2}^{+}
\end{aligned}
$$

where $\mathrm{S}$ stands for any surface site.

On the other hand, the absence of an isoelectric point is usual in clay with permanent crystalline charge like smectites [30]. 


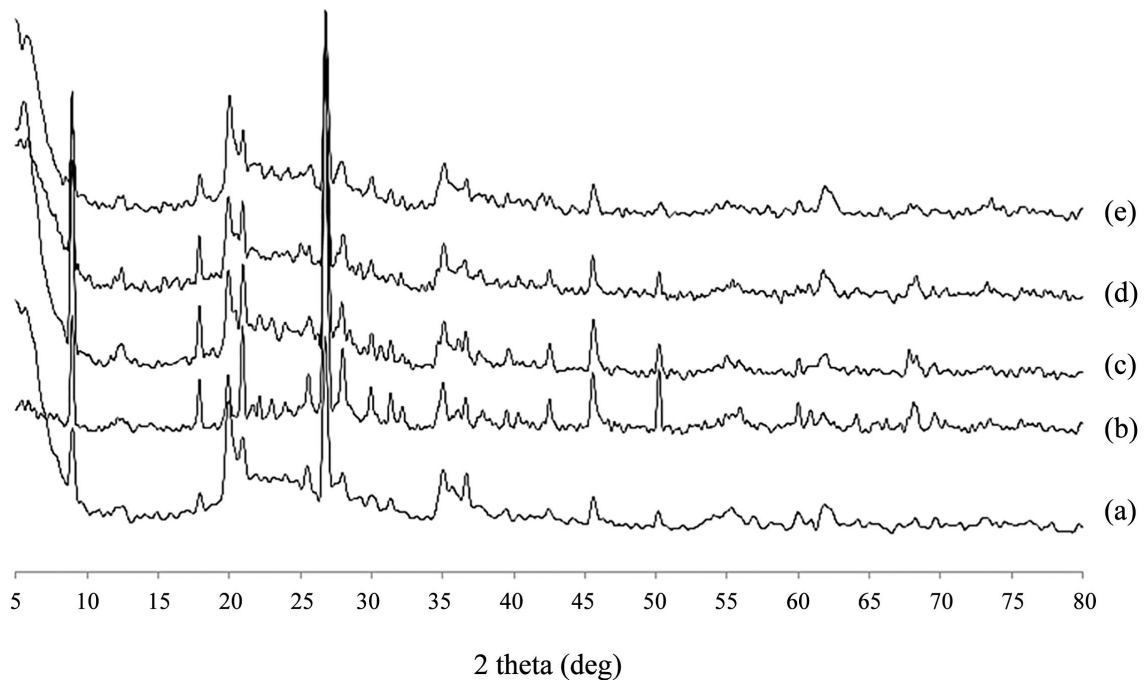

Figure 2. XRD patterns of (a) untreated Montmorillonite; and treated Montmorillonite with: (b) sodium hydroxide; (c) hydrochloric acid; (d) sulfuric acid; (e) phosphoric acid.

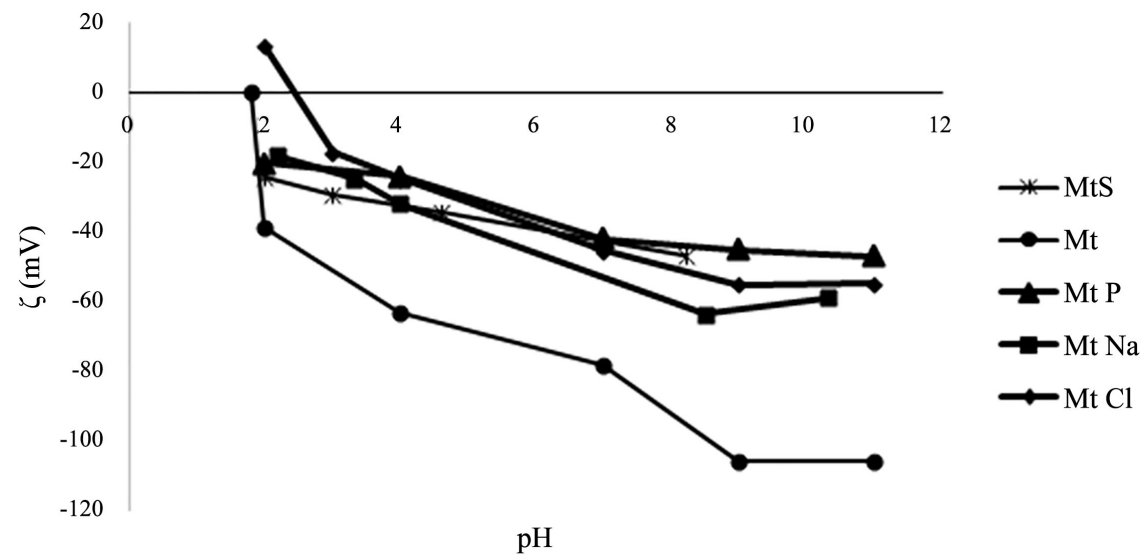

Figure 3. Zeta potential ( $\zeta$ ) of Montmorillonites as a function of $\mathrm{pH}$, at $25^{\circ} \mathrm{C}$.

\subsection{Porous Textures of the Montmorillonite}

The specific surface area $\left(\mathrm{S}_{\mathrm{BET}}\right)$, the total pore volume and the pores diameter of the treated and untreated Montmorillonite are reported in Table 2. The specific surface area of the samples ranges between 222 and $195\left(\mathrm{~m}^{2} / \mathrm{g}\right)$. The total pore volume was estimated from the volume of nitrogen helds at the relative pressure $\mathrm{P} / \mathrm{P}_{0}=1$. The average of the pores diameter is around $5.4 \mathrm{~nm}(\mathrm{DFT})$. The presence of a high $\mathrm{S}_{\mathrm{BET}}$ is considered as an important factor when the clay minerals are used as adsorbent. The decrease in pore volume due to alkaline treatment may be due to accumlation of hydroxides of cations present on the Montmorillonite.

\subsection{Comparison of the Adsorption Isotherms of Pyridine before and after Activation}

The study of the adsorption of pyridine on Montmorillonite was performed at room temperature and under atmospheric pressure with a range of concentra- 
tions between 25 and $250 \mathrm{mg} / \mathrm{L}$.

The effect of the adsorption of pyridine over the activated and non-activated Montmorillonite was studied (Figure 4). The results show that the isotherms have the same appearance. However, there is an increase of pyridine adsorption by $120 \%$ after activation by hydrochloric acid over Montmorillonite clay. A maximum value of $20.5 \mathrm{mg} / \mathrm{g}$ for activated clay was reached by comparison with $9.5 \mathrm{mg} / \mathrm{g}$ for the un-activated Montmorillonite.

This is an indication that the activation has a positive impact on the adsorption efficiency of the activated clay.

Previous studies found that the activation seems to have an enormous influence on the increase of the capacity and the efficiency of the clay adsorbed the organic molecules [31].

This increase in productivity can be justified firstly by the formation of Montmorillonite $\mathrm{H}^{+}$; this form of Montmorillonite would result from the elimination of two $\mathrm{Al}^{3+}$ of four of the central layer [32].

These transformations would leave the whole lattice of the elementary structure with a negative charge which would be immediately compensated by $\mathrm{H}^{+}$. This result confers acidity on the activated clays and increases considerably their activity.

\subsection{Effect of the Adsorbent Dose (m) towards Py Adsorption}

The effect of the adsorbent mass $(\mathrm{m}=40,60,80$ and $100 \mathrm{mg})$ on the uptake of Py by the activated MK10 was studied in the concentration range of $25-250$ $\mathrm{mg} / \mathrm{L}$. The results show (Figure 5) that the Py removal was increased rapidly with a decrease in the adsorbent mass $(\mathrm{m})$.

An increase in the adsorption capacity with a decrease of the adsorbent dose can be attributed to the increase in the availability of surface area for adsorption and hence the availability of more adsorption sites. Thus, the optimum mass for MK10 can be taken as $\mathrm{m}=40 \mathrm{mg}$ to attend the equilibrium with the value of $20.85 \mathrm{~g} / \mathrm{L}$.

\subsection{Influence of $\mathrm{pH}$ on Pyridine Adsorption over MK10 and Different Types of Activated Clay}

\subsubsection{Montmorillonite Activated by Inorganic Acids}

The effect of $\mathrm{pH}$ was studied at $\mathrm{pH}$ equal to 3, 7, 9 and 11 (Tables 3-5). The choice of this $\mathrm{pH}$ range is carried out to examine the evolution of the adsorption of solute associated with different chemical forms which are present, depending on $\mathrm{pH}$.

Pyridine adsorption isotherms over Montmorillonite activated by inorganic acids clearly show that the $\mathrm{pH}$ of the solution has a significant role on the adsorption capacity (Figure 6(a)-6(c)). Therefore, the adsorption has been shown to be more favored at $\mathrm{pH}$ equal to 7 where the molecular species $\left(\mathrm{C}_{5} \mathrm{H}_{5} \mathrm{~N}\right)$ were predominantly formed in the medium. 


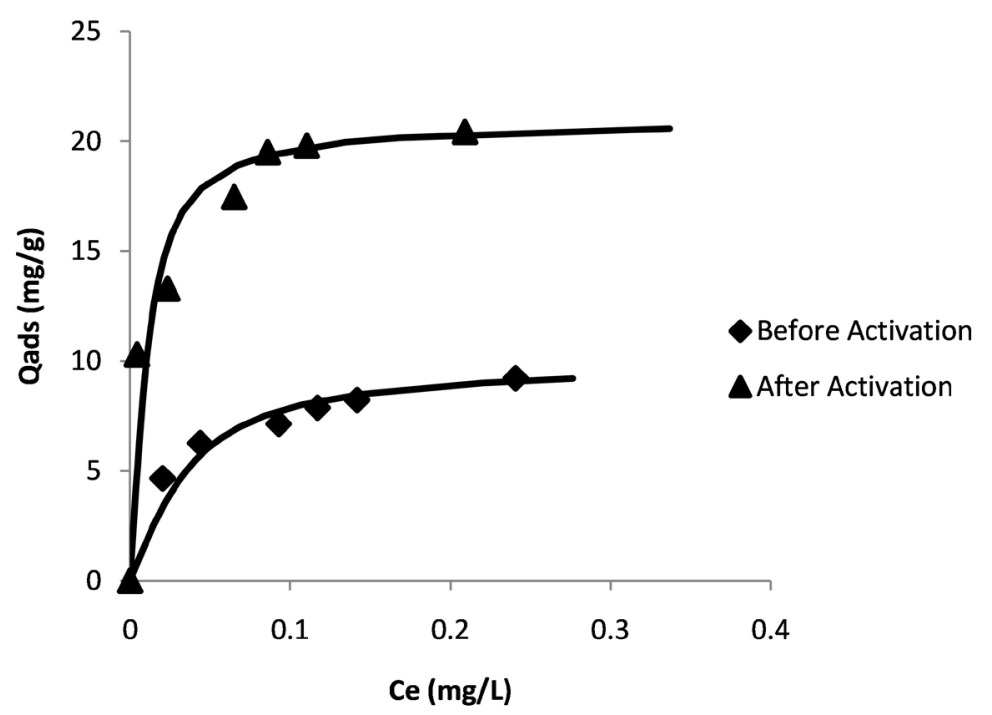

Figure 4. Adsorption isotherms of pyridine obtained before and after activation of Montmorillonite by $\mathrm{HCl}$.

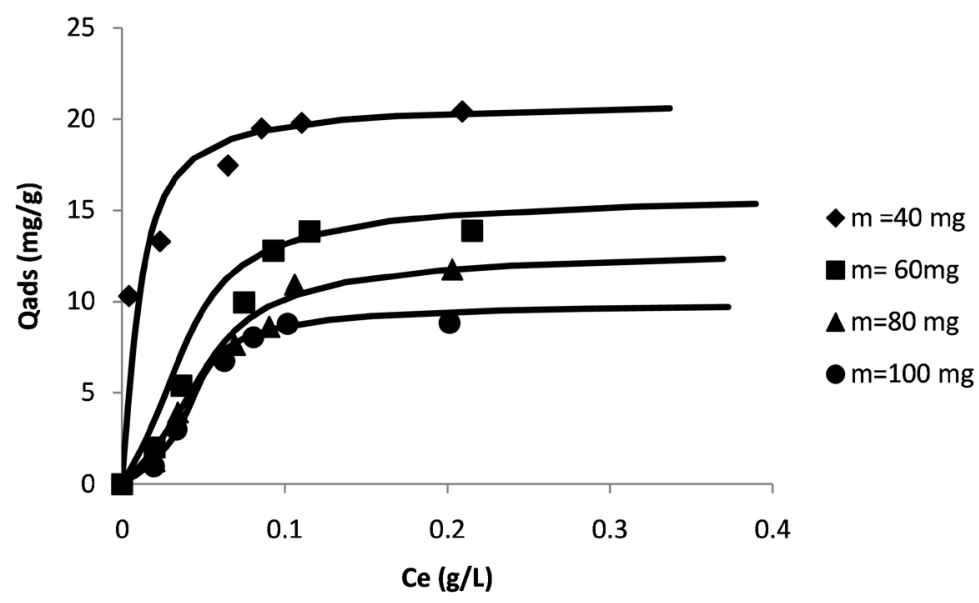

Figure 5. Effect of the mass of the adsorbent on the adsorption of pyridine over activated MK10, at room temperature.

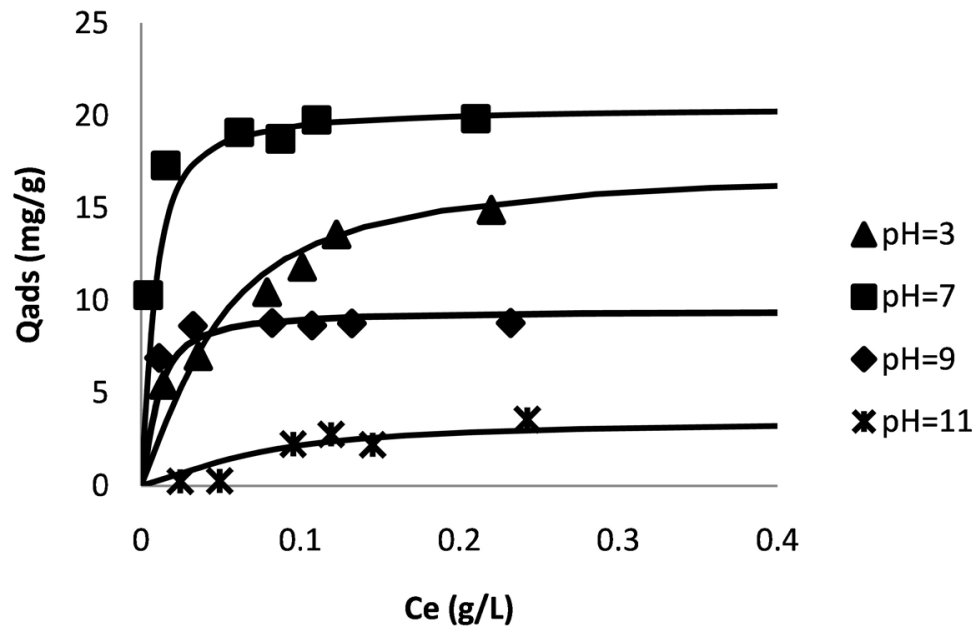

(a) 


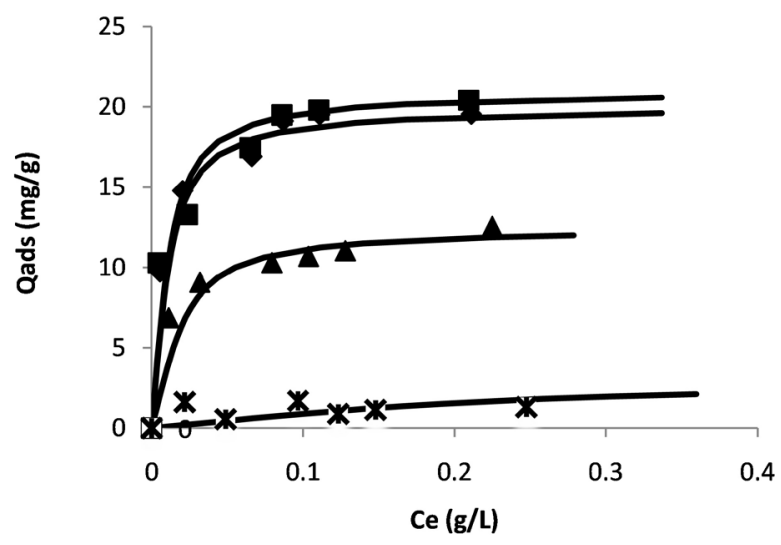

$\Delta \mathrm{pH}=3$

घH=7

$-\mathrm{pH}=9$

*pH=11

(b)

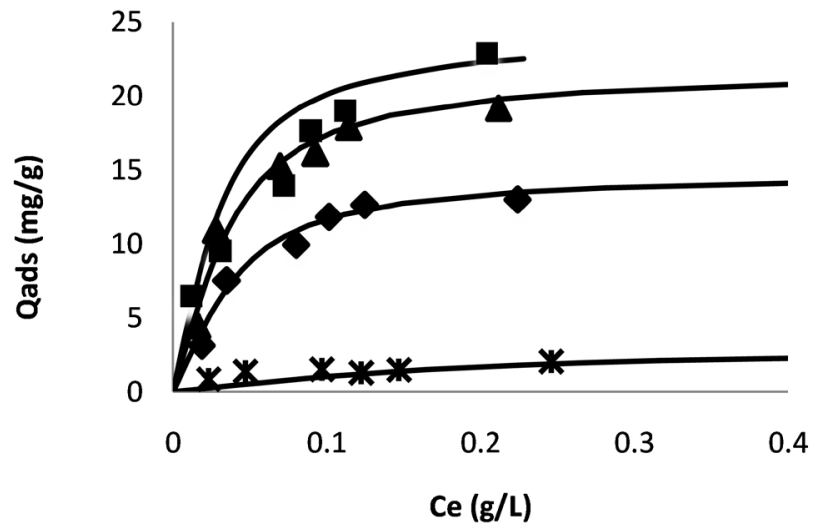

$\triangle \mathrm{pH}=3$

aH=7

- $\mathrm{pH}=9$

$\times \mathrm{pH}=11$

(c)

Figure 6. Effect of $\mathrm{pH}$ on the adsorption of pyridine at room temperature over MK10 activated by (a) phosphoric acid; (b) hydrochloric acid; (c) sulfuric acid.

Table 2. Textural properties resulting from the analysis of N2 adsorption isotherms of the treated and untreated Montmorillonites.

\begin{tabular}{|c|c|c|c|c|c|}
\hline Abbreviation & Mt & $\mathrm{MtCl}$ & $\mathrm{MtP}$ & MtS & $\mathrm{MtNa}$ \\
\hline $\operatorname{SBET}\left(\mathrm{m}^{2} / \mathrm{g}\right)$ & 222 & 215 & 218 & 216 & 195 \\
\hline Total porous Volume $\left(\mathrm{cm}^{3} / \mathrm{g}\right)$ & 0.315 & 0.273 & 0.299 & 0.30 & 0.218 \\
\hline Microporous Volume $\left(\mathrm{cm}^{3} / \mathrm{g}\right)$ & 0.036 & 0.037 & 0.039 & 0.04 & 0.033 \\
\hline Mesoporous Volume $\left(\mathrm{cm}^{3} / \mathrm{g}\right)$ & 0.279 & 0.236 & 0.26 & 0.26 & 0.185 \\
\hline $\begin{array}{l}\text { Average of the Pores } \\
\text { Diameter }(\mathrm{nm})\end{array}$ & 5.4 & 5.4 & 5.4 & 5.4 & 5.4 \\
\hline
\end{tabular}

Table 3. Parameter values of Fowler-Guggenheim Model obtained from isotherms of pyridine adsorption over Montmorillonite activated by hydrochloric acid.

\begin{tabular}{ccccc}
\hline $\mathrm{pH}$ & 3 & 7 & 9 & 11 \\
\hline $\mathrm{K}(\mathrm{L} / \mathrm{g})$ & 30 & 54.6 & 54.6 & 3 \\
$\mathrm{~W}(\mathrm{~J} / \mathrm{mol})$ & -1340 & -1220 & -1220 & -1330 \\
Qads $(\mathrm{mg} / \mathrm{g})$ & 12.3 & 20.5 & 20 & 1.5 \\
\hline
\end{tabular}


Table 4. Parameter values of Fowler-Guggenheim Model obtained from isotherms of pyridine adsorption over Montmorillonite activated by sulfuric acid.

\begin{tabular}{ccccc}
\hline $\mathrm{pH}$ & 3 & 7 & 9 & 11 \\
\hline $\mathrm{K}(\mathrm{L} / \mathrm{g})$ & 16.5 & 20 & 14.5 & 3.1 \\
$\mathrm{~W}(\mathrm{~J} / \mathrm{mol})$ & -1280 & -1220 & -1300 & -1230 \\
Qads $(\mathrm{mg} / \mathrm{g})$ & 20.5 & 25.5 & 13.7 & 1.5 \\
\hline
\end{tabular}

Table 5. Parameter values of Fowler-Guggenheim Model obtained from isotherms of pyridine adsorption over Montmorillonite activated by phosphoric acid.

\begin{tabular}{ccccc}
\hline $\mathrm{pH}$ & 3 & 7 & 9 & 11 \\
\hline $\mathrm{K}(\mathrm{L} / \mathrm{g})$ & 55 & 66.6 & 49 & 7 \\
$\mathrm{~W}(\mathrm{~J} / \mathrm{mol})$ & -1340 & -1340 & -1500 & -1400 \\
Qads $(\mathrm{mg} / \mathrm{g})$ & 16.5 & 20.5 & 9.5 & 3.5 \\
\hline
\end{tabular}

Some studies indicated that [33], the replacement of $\mathrm{K}^{+}$ions with $\mathrm{H}^{+}$ions by lowering $\mathrm{pH}$ completely removed the additional repulsive forces. In acid solution, all the hydration repulsive forces exist at the surface of the Montmorillonite were removed due to the diffusion of $\mathrm{H}^{+}$ion into the interlayers and neutralizing the surface hydroxyl group.

At $\mathrm{pH} 3$, a decrease in the amount of adsorption is observed, this can be explained by the surface weakly negative of the Montmorillonite at this $\mathrm{pH}$, and thus a weak interaction takes place between the associated species $\mathrm{C}_{5} \mathrm{H}_{5} \mathrm{NH}^{+}$positively charged and the surface weakly negative.

Whereas at $\mathrm{pH} 11$, a strong interaction between $\mathrm{OH}^{-}$of the solution and the cations present in the structure, which reduces the adsorption capacity with respect to pyridine.

The various values determined from the Fowler-Guggenheim model are reported in Tables 3-5.

A good correlation was found between these parameters and the results obtained:

The interaction constant $\mathrm{K}$, between the adsorbent and the adsorbate, was more important over Montmorillonite at $\mathrm{pH}=7$. On the other hand, the interaction energy between the adsorbed molecules (W) is constant and is of the order of $-1.2 \mathrm{~kJ} / \mathrm{mol}$ whatever the type of the used acid.

\subsubsection{Effect of Acid Type}

The influence of activating agents of montmorillonite on adsorption of pyridine was investigated using different types of acid. The effect of uptake was studied using the following conditions: $\mathrm{pH}=7$, Pyridine $=250 \mathrm{mg} / \mathrm{L}$, activated montmorillonite $=2 \mathrm{~g} / \mathrm{L}$.

As can be noticed in Figure 7, the equilibrium capacity was slightly affected by using $\mathrm{H}_{2} \mathrm{SO}_{4}$ by comparison with that obtained by using $\mathrm{HCl}$ and $\mathrm{H}_{3} \mathrm{PO}_{4}$.

It was reported that sulphuric acid is preferred because it does not evaporate 
during the acid activation step, thus permitting a more complete activation of the clay. The authors also stated that phosphoric acid has a similar action, but poorly soluble aluminum phosphate is formed. However, it does not migrate into the pores easily. Hydrochloric acid is less desirable as an activating acid, as it evaporates during activation and forms soluble salts which can be washed out of the micropores of the clay product [34].

That is why, for the remainder of this work, Montmorillonite activated by $\mathrm{H}_{2} \mathrm{SO}_{4}$ is selected.

\subsubsection{Montmorillonite Activated by $\mathrm{NaOH}$}

The effect of the alkaline activation $(\mathrm{NaOH})$ was studied for several solutions of Py having different $\mathrm{pH}$. $\mathrm{NaOH}$ was chosen because a relatively low concentration and lower cost were required for the activation process compared to $\mathrm{KOH}$ [35]. The results show (Table 6) that the maximum adsorption of pyridine was observed at $\mathrm{pH}=3$ (Figure 8). This increase of pyridine-sorption at acidic $\mathrm{pH}$ might because of the increase of the surface with hydroxyl ions resulting from the alkaline activation and the strong interaction taking place between the associated species $\mathrm{C}_{5} \mathrm{H}_{5} \mathrm{NH}^{+}$, positively charged, and the surface. The decrease in maximal adsorption capacity by alkaline activation comparing with acidic Montmorillonite could be due to decrease in BET surface area (Table 2).

\subsection{Influence of Temperature on Pyridine Adsorption}

The influence of temperature on the adsorption of pyridine was studied between $20^{\circ} \mathrm{C}$ and $40^{\circ} \mathrm{C}$.

The results indicated that the adsorption capacity was decreased as temperature was increased. This come from the fact that pyridine adsorption by activated Montmorillonite is an exothermic process. That is also observed with the parameters of the fowler-Guggenheim model (Table 7). $\mathrm{K}$ is the equilibrium constant for the adsorption of the adsorbate on an active site. It represents the interaction between the adsorbate and the adsorbent.

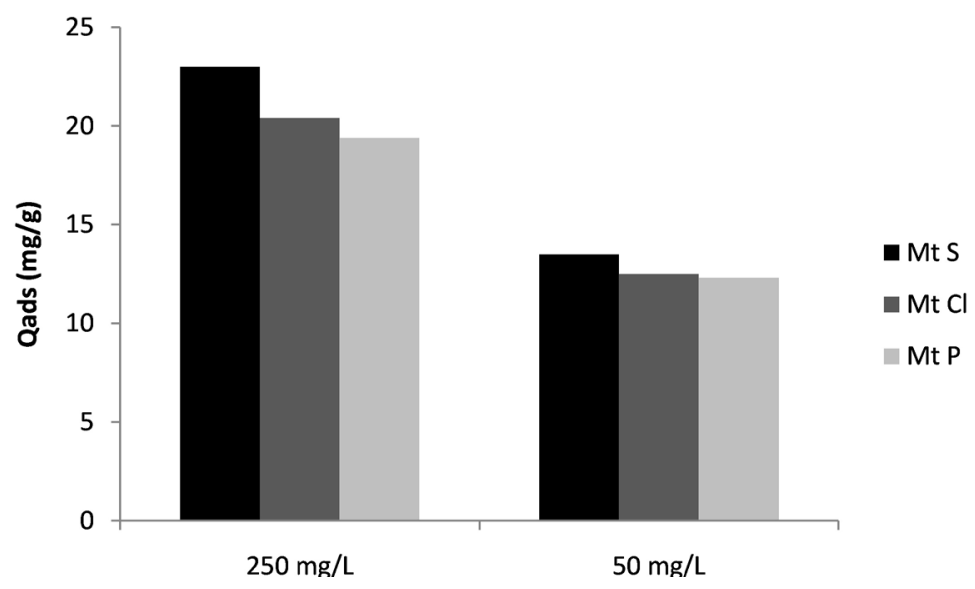

Figure 7. Influence of acid types as activating agents of Montmorillonite on adsorption of pyridine at room temperature and $\mathrm{pH}=7$. 


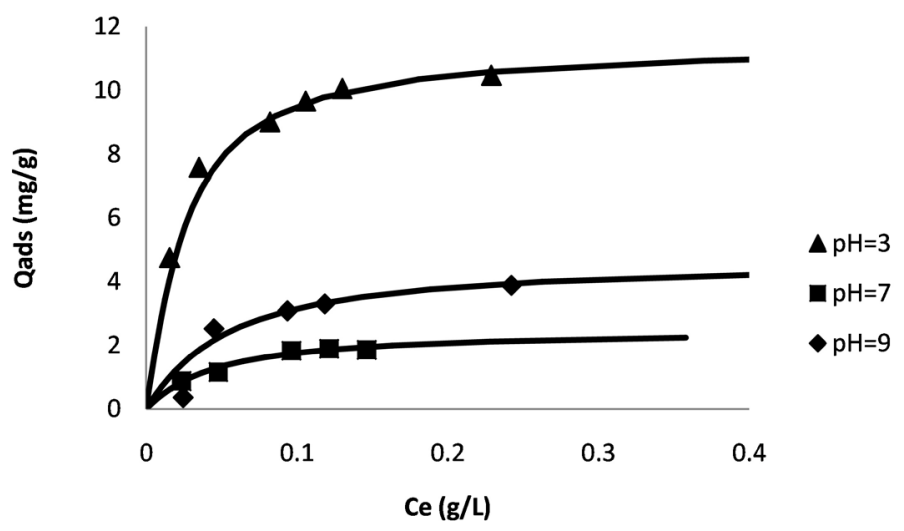

Figure 8. Effect of $\mathrm{pH}$ on the adsorption of pyridine over Montmorillonite activated by sodium hydroxide $(\mathrm{MtNa})$, at room temperature.

Table 6. Parameter values of Fowler-Guggenheim Model obtained from isotherms of pyridine adsorption over Montmorillonite activated with Sodium Hydroxide.

\begin{tabular}{cccc}
\hline $\mathrm{pH}$ & 3 & 7 & 9 \\
\hline $\mathrm{K}(\mathrm{L} / \mathrm{g})$ & 20 & 10 & 12 \\
$\mathrm{~W}(\mathrm{~J} / \mathrm{mol})$ & -1095 & -1050 & -950 \\
Qads $(\mathrm{mg} / \mathrm{g})$ & 10 & 3 & 4 \\
\hline
\end{tabular}

Table 7. Thermodynamics parameters for the adsorption of pyridine over activated Montmorillonite MtS.

\begin{tabular}{cccc}
\hline $\mathrm{T}\left({ }^{\circ} \mathrm{C}\right)$ & 20 & 30 & 40 \\
\hline $\mathrm{K}(\mathrm{L} / \mathrm{g})$ & 54.5 & 46.7 & 40.4 \\
$\mathrm{~W}(\mathrm{~J} / \mathrm{mol})$ & -1460 & -1580 & -1820 \\
Qads $(\mathrm{mg} / \mathrm{g})$ & 19.6 & 18.13 & 14.67 \\
$\Delta \mathrm{G}^{\circ}(\mathrm{J} / \mathrm{mol})$ & -9540 & -9480 & -9420 \\
$\Delta \mathrm{H}^{\circ}(\mathrm{J} / \mathrm{mol})$ & $-11,240$ & $-11,240$ & $-11,240$ \\
$\Delta \mathrm{S}^{\circ}(\mathrm{J} / \mathrm{mol} . \mathrm{K})$ & -5.8 & -5.8 & -5.8 \\
\hline
\end{tabular}

Therefore, the highest $\mathrm{K}$ value at $\mathrm{T}=20^{\circ} \mathrm{C}(54.5 \mathrm{~L} / \mathrm{g})$ than that at $\mathrm{T}=30^{\circ} \mathrm{C}$ $(\mathrm{K}=46.7 \mathrm{~L} / \mathrm{g})$ and $\mathrm{T}=40^{\circ} \mathrm{C}(\mathrm{K}=40 \mathrm{~L} / \mathrm{g})$ indicates the important interaction between pyridine molecules and the Montmorillonite at lower temperature. As the adsorption process is spontaneous, the free energy change $\left(\Delta G^{\circ}\right)$ must be less than zero. Moreover, $\Delta \mathrm{H}^{\circ}$ is also negative since the adsorption is exothermic (Table 7).

According to equilibrium shift principle, the increase of temperature encumbers adsorption since it causes a decrease in the value of the free energy change and thus a decrease in the spontanousity of the adsorption process.

\section{Mechanism of Pyridine Adsorption on Montmorillonite}

The sorption mechanism of pyridine on Montmorillonite has been investigated firstly using IRTF spectroscopy.

By comparing the two Montmorillonite spectra before and after pyridine 
adsorption (Figure 9), several peaks show shift in the frequency of absorption bands. This is due to the interaction of the corresponding functional groups with pyridine. Shifts were observed for the bands corresponding to $\mathrm{Si}-\mathrm{O}$ bending from 1046 to 1048, Si-O-Al symmetrical stretching, from 531 and 469 to 527 and 466, indicating that pyridine interacts with Montmorillonite at $\mathrm{Si}-\mathrm{O}$ sites.

New peaks appear in the spectrum of Montmorillonite after pyridine adsorption at 690 and 1480 with low intensities. These new-appearing peaks correspond to the vibration of the $\mathrm{C}-\mathrm{H}$ and $\mathrm{C}-\mathrm{C}$ bonds of pyridine. This result assures that pyridine was adsorbed principally by hydrogen bonding.

The thermal behavior and mass loss of Montmorillonite before and after adsorption as investigated by TGA analysis is presented in Figure 10. The Montmorillonite before adsorption exhibited a total mass loss of $12 \%$ between $30^{\circ} \mathrm{C}$ and $800^{\circ} \mathrm{C}$. Between $30^{\circ} \mathrm{C}$ and $200^{\circ} \mathrm{C}$, the mass loss was $6 \%$, corresponding to the loss of most of the surface and interlayer space water. This was followed by a slow $5 \%$ mass loss between $200^{\circ} \mathrm{C}$ and $600^{\circ} \mathrm{C}$, likely due to dehydration of residual interlayer space water that may have been more tightly bound due to cation bridging. At temperatures above $600^{\circ} \mathrm{C}$, the Montmorillonite exhibited a $1 \%$ mass loss due to dehydroxylation.

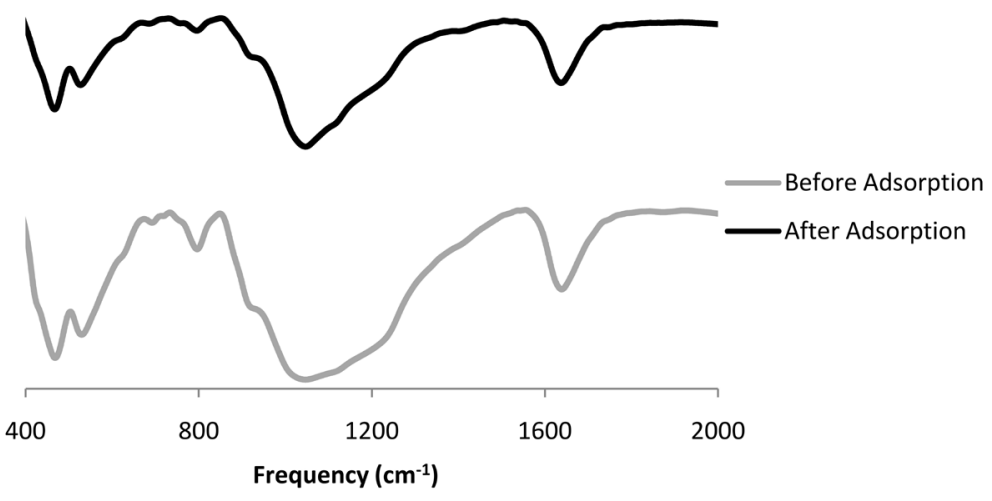

(a)
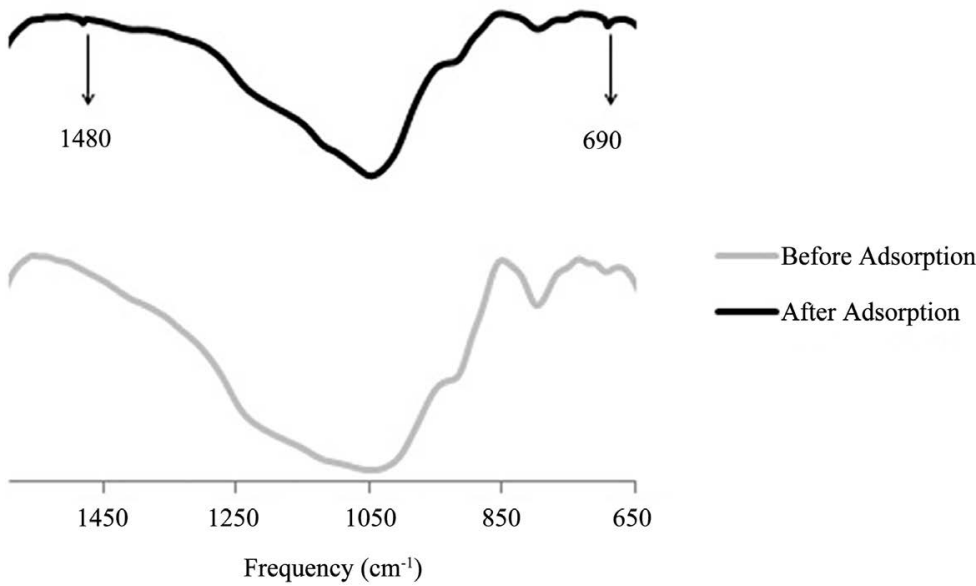

(b)

Figure 9. FTIR spectra of Montmorillonite MtS before and after pyridine adsorption. (a) Between $400-2000 \mathrm{~cm}^{-1}$; (b) between $650-1500 \mathrm{~cm}^{-1}$. 


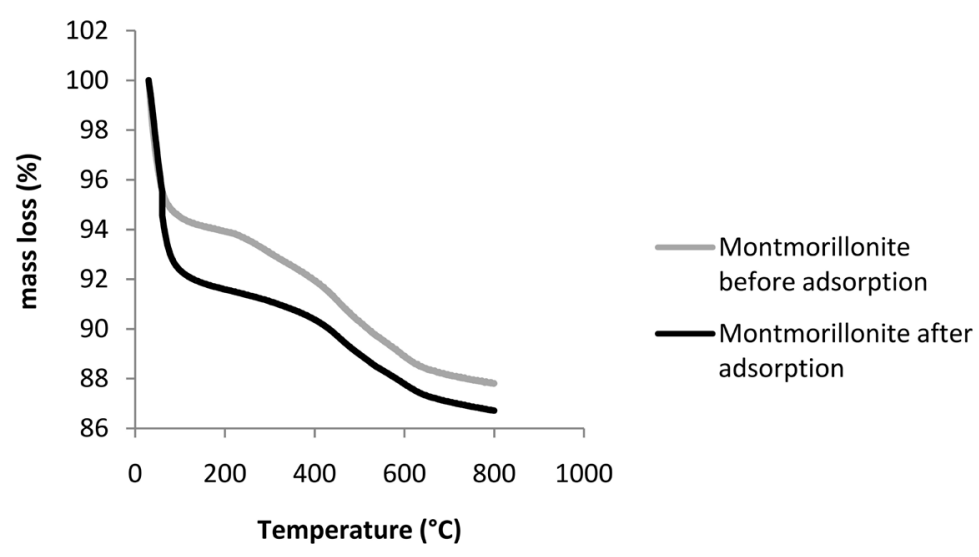

Figure 10. TGA curves of the Montmorillonite MtS before and after pyridine adsorption.

It is clear from the thermogram of the Montmorillonite after pyridine adsorption that the mass loss between $90^{\circ} \mathrm{C}$ and $120^{\circ} \mathrm{C}$ is bigger than that obtained for the Montmorillonite before adsorption, these new mass loss is due to pyridines molecules adsorbed over Montmorillonite. The Montmorillonite after adsorption experienced greater mass loss at lower temperature, indicating that the pyridines were more absorbed into the external surface and confirm the results obtained by FTIR.

\section{Conclusions}

The release in the nature of toxic compounds resulting from industrial facilities constitutes a real problem which requires a rapid treatment in order to prevent the environmental pollution.

The purpose of this study is the use of economical material to adsorb at low concentration the pyridine $(\mathrm{Py})$ molecule, which is a naturally occurring alkaloid found in many plants. An inexpensive adsorbent "Montmorillonite clay" is chosen to adsorb pyridine.

It presents the advantages to be low-cost, available and it shows good adsorption properties towards many organic compounds. More precisely, the Montmorillonite clay can be easily activated by acid to become a promising adsorbent for pyridine removal from aqueous solution.

The effect of various parameters, such as adsorbent dose, $\mathrm{pH}$, contact time and temperature on the removal of pyridine, a series of batch adsorption studies were carried out in order to determine the optimal experimental conditions which allow to obtain a higher adsorption. The results showed that the best adsorption of pyridine is obtained under neutral $\mathrm{pH}$, at room temperature and using a lower mass of the clay adsorbent. Results obtained by FTIR and thermogravimetry proved that adsorption of pyridine had occurred by physical interactions as hydrogen bond interactions. The equilibrium data were well described by the Fowler-Guggenheim model. Thermodynamic calculations indicated that the adsorption of pyridine over Montmorillonite was spontaneous and exothermic reaction. These observations are important in terms of economic interest as 
well as environmental protection.

\section{Acknowledgements}

This work supported by Laboratory of Materials, Catalysis, Environment \& Analytical Methods (MCEMA) and by Laboratory of Applied Studies for Sustainable Development and Renewable Energy (LEADDER) at the Lebanese University.

\section{Conflicts of Interest}

The authors declare no conflicts of interest regarding the publication of this paper.

\section{References}

[1] Wolfe, T., Demirel, T. and Baumann, R. (1985) Interaction of Aliphatic Amines with Montmorillonite to Enhance Adsorption of Organic Pollutants. Clays and Clay Minerals, 33, 301-311. https://doi.org/10.1346/CCMN.1985.0330405

[2] Dinesh, M., Kunwar, P.S., Sinha, S. and Deblina, G. (2004) Removal of Pyridine from Aqueous Solution Using Low Cost Activated Carbons Derived from Agricultural Waste Materials. Carbon, 42, 2409-2421. https://doi.org/10.1016/j.carbon.2004.04.026

[3] Yewale, A.G., Patil, N.D. and Patwardhan, A.W. (2016) Removal of Pyridine from Dilute Aqueous Solution Using Hollow Fiber Supported Liquid Membranes. Desalination and Water Treatment, 57, 18939-18955. https://doi.org/10.1080/19443994.2015.1093550

[4] Dinesh, M., Kunwar, P.S., Sinha, S. and Deblina, G. (2005) Removal of Pyridine Derivatives from Aqueous Solution by Activated Carbons Developed from Agricultural Waste Materials. Carbon, 43, 1680-1693. https://doi.org/10.1016/j.carbon.2005.02.017

[5] Lataye, D.H., Mishrax, I.M. and Malla, I.D. (2008) Pyridine Sorption Aqueous by Rice Husk Ash (RHA) and Granular Activated carbon (GAC): Parametric, Kinetic, Equilibrium and Thermodynamic Aspects. Journal of Hazardous Materials, 154, 858-870. https://doi.org/10.1016/j.jhazmat.2007.10.111

[6] Reháková, M., Fortunová, L., Bastl, Z., Nagyová, S., Dolinská, S., Jorík, V. and Jóna, E. (2011) Removal of Pyridine from Liquid and Gas Phase by Copper Forms of Natural and Synthetic Zeolites. Journal of Hazardous Materials, 186, 699-706. https://doi.org/10.1016/j.jhazmat.2010.11.051

[7] Djebbar, M., Djafri, F., Bouchekara, M. and Djafri, A. (2012) Adsorption of Phenol on Natural Clay. African Journal of Pure and Applied Chemistry, 6, 15-25.

[8] Luh, M.D. and Baker, R.A. (1971) Sorption and Desorption of Pyridine-Clay in Aqueous Solution. Water Research, 10, 848-849. https://doi.org/10.1016/0043-1354(71)90021-2

[9] Baker, R.A. and Luh, M.D. (1971) Pyridine Sorption from Aqueous Solution by Montmorillonite and Kaolinite. Water Research, 5, 839-848. https://doi.org/10.1016/0043-1354(71)90020-0

[10] Shu, H.T., Li, D., Scala, A.A. and Ma, Y.H. (1997) Adsorption of Small Organic Pollutants from Aqueous Streams by Aluminosilicate-based Microporous Materials, Separation and Purification Technology, 11, 27-36. 
https://doi.org/10.1016/S1383-5866(96)01005-2

[11] Bludau, H., Karge H.G. and Niessen, W. (1998) Sorption Kinetics and Diffusion of Pyridine in Zeolites. Microporous and Mesoporous Materials, 22, 297-308. https://doi.org/10.1016/S1387-1811(98)00093-6

[12] Koubaissy, B., Joly, G. and Magnoux, P. (2008) Adsorption and Competitive on Zeolites of Nitrophenol Compounds Present in Wastewater. Industrial \& Engineering Chemistry Research, 47, 9558-9565. https://doi.org/10.1021/ie8001777

[13] Schick, J., Daou, T.J., Caullet, P., Paillaud, J., Patarin, J. and Mangold-Callarec, C. (2011) Surfactant-Modified MFI Nanosheets: A High Capacity Anion-Exchanger. Chemical Communication, 47, 902-904. https://doi.org/10.1039/C0CC03604H

[14] Bai, Y., Sun,Q., Xing, R., Wen, D. and Tang, X. (2010) Removal of Pyridine and Quinoline by Bio-Zeolite Composed of Mixed Degrading Bacteria and Modified Zeolite. Journal of Hazardous Materials, 181, 916-922. https://doi.org/10.1016/j.jhazmat.2010.05.099

[15] Djoufac Woumfo, E., Rivallan, M., Minkoulou, A.H., Nkot, E.O., Figueras, F. and Njopwouo, D. (2012) River water Discolouration with Acid Activated Kaolinite-Rich Clays. The Open Catalysis Journal, 5, 31-38.

[16] Bendou, S. and Amrani, M. (2014) Effect of Hydrochloric Acid on the Structural of Sodic-Bentonite Clay. Journal of Minerals and Materials Characterization and Enginnering, 2, 404-413. https://doi.org/10.4236/jmmce.2014.25045

[17] Noyan, H., Onal, M. and Sarikaya, Y. (2007) The Effect of Sulfuric Acid Activation on the Crystallinity, Surface Area, Porosity, Surface Acidity, and Bleaching Power of a Bentonite. Food Chemistry, 105, 156-163. https://doi.org/10.1016/j.foodchem.2007.03.060

[18] Singla, P., Mehta, R. and Upadhyay, S. (2012) Clay Modification by the Use of Organic Cations. Green and Sustainable Chemistry, 2, 21-25. https://doi.org/10.4236/gsc.2012.21004

[19] He, H.P., Tao, Q., Zhu, J.X., Yuan, P., Shen, W. and Yang, S.Q. (2013) Silylation of Clay Minerals Surface. Applied Clay Science, 71, 15-20. https://doi.org/10.1016/j.clay.2012.09.028

[20] Salles, F., Douillard, J.M., Bildstein, O., Ghazi, S., Prélot, B., Zajac, J. and Van Damme, H. (2015) Diffusion of Interlayer Cations in Swelling Clays as a Function of Water Content: Case of Montmorillonies Saturated with Alkali Cations. The Journal of Physical Chemistry C, 119, 10370-10378. https://doi.org/10.1021/jp512986d

[21] Park, Y., Ayoko, G.A. and Frost, R. (2011) Application of Organoclays for the Adsorption of Recalcitrant Organic Molecules from Aqueous Media. Journal of Colloid and Interface Science, 354, 292-305. https://doi.org/10.1016/j.jcis.2010.09.068

[22] Siantar, D., Feinberg, B. and Fripiat, J. (1994) Interaction between Organic and Inorganic Pollutants in the Clay Interlayer. Clays and Clay Minerals, 42, 187-196. https://doi.org/10.1346/CCMN.1994.0420209

[23] Tyagi, B., Chudasam, C. and Jasra, R. (2006) Determination of Structural Modification in Acid Activated Montmorillonite Clay by FT-IR Spectroscopy. Spectrochimica Acta Part A: Molecular and Biomolecular Spectroscopy, 64, 273-278. https://doi.org/10.1016/j.saa.2005.07.018

[24] Russell, J.D. and Fraser, A.R. (1994) Clay Mineralogy: Spectroscopic and Chemical Determinative Methods. Chapman \& Hall, London, 11-67.

https://doi.org/10.1007/978-94-011-0727-3_2 
[25] Korichi, S., Elias, A. and Mefti, A. (2009) Characterization of Smectite after Acid Activation with Microwave Irradiation. Applied Clay Science, 42, 432-438. https://doi.org/10.1016/j.clay.2008.04.014

[26] Vicente-Rodriguez, M.A., Suárez, M., Baňares-Muňoz, M.A. and López González, J.D. (1996) Comparative FT-IR Study of the Removal of Octahedral Cations and Structural Modifications during Acid Treatment of Several Silicates. Spectrochimica Acta Part A: Molecular and Biomolecular Spectroscopy, 52, 1685-1694. https://doi.org/10.1016/S0584-8539(96)01771-0

[27] Sakrane, S. (2014) Préparation, caractérisation et réactivité catalytique des nanoparticules d'or supportés sur argile. Mémoire, Université Ferhat Abbas Sétif-1, Algérie.

[28] Bharadwaj, S., Boruah, P. and Gogoi, P. (2014) Phosphoric Acid Modified Montmorillonite Clay: A New Heterogeneous Catalyst for Nitration of Arenes. Catalysis Communications, 5, 124-128. https://doi.org/10.1016/j.catcom.2014.08.019

[29] Avena, M., Cabrol, R. and De Pauli, C. (1990) Study of Some Physicochemical Properties of Pillared Montmorillonites: Acid-Base Potentiometric Titrations and Electrophoretic Measurements. Clays and Clay Minerals, 38, 356-362. https://doi.org/10.1346/CCMN.1990.0380404

[30] Thomas, F., Michot, L.J., Vantelon, D., Montarges, E., Prelot, B., Cruchaudet, M. and Delon, J.F. (1999) Layer Charge and Electrophoretic Mobility of Smectites. Colloids and Surface, 159, 351-358. https://doi.org/10.1016/S0927-7757(99)00291-5

[31] Seghairi, N. and Achour, S. (2003) Influence du temps et du taux d'activation de la Bentonite sur l'adsorption de l'Aniline. Larhyss Journal, No. 2, 115-125.

[32] Ravichandran, J. and Sivasankar, B. (1997) Properties and Catalytic Activity of Acid-Modified Montmorillonite and Vermiculite. Clays and Clays Minerals, 45, 854-858. https://doi.org/10.1346/CCMN.1997.0450609

[33] Altin, O., Özbelge, H.Ö. and Dogu, T. (1999) Effect of pH in an Aqueous Medium on the Surface Area, Pore Size Distribution, Density, and Porosity of Montmorillonite. Journal of Colloid and Interface Sciences, 217, 19-27. https://doi.org/10.1006/jcis.1999.6271

[34] David, H., Christian, P.F. and Jorge, B. (2002) Processes for Producing Bleaching Clay Product. US Patent No. 6759359BI.

[35] Salawudeen, T.O., Arinkoola, A.O., Jimoh, M.O. and Akinwande, B.A. (2014) Clay Characterization and Optimisation of Bleaching Parameters for Palm Kernel Oil Using Alkaline Activated Clays. Journal of Minerals and Materials Characterization and Engineering, 2, 586-597. https://doi.org/10.4236/jmmce.2014.26060 